\title{
TWS19-7 感情の精神生理学的測定
}

\author{
講師 : 手塚 洋介 (大阪体育大学) \\ 講師 : 藤村 友美 (科学技術新興機構ERATO岡ノ谷情動情報プロジェクト)
}

感情の精神生理学研究を新たに始めようとした場合に, 実験環境の設定や測定法の選択, データの解 釈に至るまで, 多くの困難を伴う。このワークショップでは, 表情筋活動と自律神経活動に焦点を当て, 感情の精神生理学的手法に関する情報提供を図ることを目的としている。当日は, 各種指標の測定法, 各指標を用いた研究の標準的な実験プロトコル, 実際の研究例などの紹介に加え, 未梢神経系の生理学 的測定を実演する。

キーワード : 感情の精神生理学・表情筋・筋電図・自律神経系・心電図

\section{事前学習 (参考文献)}

$\mathrm{J}$ ・八セット平井久・坚玉昌久 - 山中祥男（編訳）（1987）. 精神生理学入門 東京大学出版会

加藤 象二郎・大久保 堯夫（編）（2006）。初学者のための生体機能の測り方（第 2 版）日本出版サービス 